\title{
The Evaluation of Interiority in the Identity of Public Spaces
}

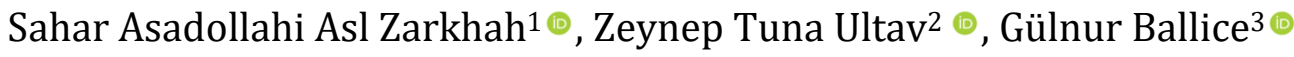 \\ ${ }^{1}$ Architect, Master of interior architecture, Email: sahar.asadolahi@gmail.com \\ ${ }^{2}$ Associate Professor, Department of Interior Architecture and Environmental Design, Faculty of Architecture, Yaşar \\ University, Izmir, Turkey. Email: zeynep.tunaultav@yasar.edu.tr \\ 3 Associate Professor, Department of Interior Architecture and Environmental Design, Faculty of Architecture, Yaşar \\ University, Izmir, Turkey. (Principal contact for editorial correspondence), Email: gulnur.ballice@yasar.edu.tr
}

\begin{abstract}
Purpose

Public spaces in the context of everyday life in an urban environment include all places with public access and public use. Places for public interaction provide the greatest amount of human contact. In every city, many interiors are considered public because they are of or pertain to the people in everyday life. As part of public spaces, public interiors have an important role in creating place identity.

In an urban environment, place identity is defined by meanings as well as the elements of setting, activities, and events taking place within that environment. This paper aims to reveal the interiority attributes and elements of public interiors to determine how they influence the identity of interior places. This understanding clarifies how this differs from the more general concept of place identity in public spaces.
\end{abstract}

Design/Methodology/Approach

To do this, a framework for identity was constructed with three components: physical setting, activity, and meaning, based on the main theoretical perspectives of Relph (1976) and Montgomery (1998). To determine the relationships between the interiority indicators of public interiors and identity, this case study focused on Kızlarağası Inn, a historic inn in İzmir, and its immediate surroundings. Data concerning the components of place identity were collected through archival research, observations, on-site documentation, questionnaires, interviews, behavior mapping, and tracking.

\section{Findings}

The analysis of the attributes and elements of place identity in this public interior indicated that the interiority of public spaces can play a positive role in increasing place identity. Moreover, the evaluations revealed the effect of internality in each component of place identity. Features like welldefined boundaries, closeness to human scale, volumetric properties, legibility, the potential of promoting a wide range of activities, and promoting a different sensory context stem from the internality of place.

\section{Social/Practical Implications}

This study emphasized the importance of public and urban interiors as significant places that facilitate public life. Moreover, it showed the extension of interior spaces outside the buildings, which emphasized a new perspective for interior architects and urban designers by bringing a new understanding of the interiority.

Keywords: Interiority, place identity, public interior, public space, Kızlarağası Inn 


\section{INTRODUCTION}

In the everyday life of an urban neighborhood, the public realm to which public have physical and visual access as part of the urban framework is important for towns and cities since it is here where human contact and interaction are greatest (Tibbalds, 2012). The term "public space", defined as all places with public access and public use, highlights the connation between people and space. "Public space is the common ground where people carry out the functional and ritual activities that bind a community" (Carr et al., 1992).

As part of this public space, public interiors also play a significant role in creating place identity. According to Harteveld (2014), interior public spaces have always played significant roles in various social-spatial changes, making them crucial to cities and their culture. These spaces are parts of everyday urban life; places for socio-spatial transformation.

In every city, many interiors are referred to as public because they are of or pertain to people in everyday life in the sense that they belong to the people, regardless of government laws and regulations.

Public interiors acquire distinct cultural meanings in different cities or societies due to social adaptation and spatial transformation. Over time, each public space develops its cultural meaning and social value; its unique history and future. The public quality of an interior or any public space formed by public use depends on the specific culture of a city and its specific socio-spatial contexts, which influence each other (Harteveld, 2014).

Defined more extensively, public interiors can be seen as both inside and outside buildings for public use and public interaction. The increasing intersection of the concepts of "public" and "interior" in the context of everyday life in an urban environment raises the important matter of the relationships and interactions of these urban spaces with their users.

According to McCarthy (2005, p. 112), "Interiority is that abstract quality that enables the recognition and definition of an interior". The interior is made possible through a theoretical and immaterial set of coincidences and variables. As he notes, interiority means that interiors are controlled, which makes them potentially controlling environments that restrict possibilities within them. Consequently, they rely on sensual acoustic, haptic, olfactory, tactile, visual, climatic, physical, and social conditions to remain intimate and elastic (McCarthy, 2005).

In an urban environment, place identity is defined by meanings as well as the elements of setting, activities, and events taking place within that environment. This paper investigates the interiority attributes and elements of public interiors to determine how they influence the identity of interior places. This understanding clarifies how this differs from the more general concept of place identity in public spaces.

In this study, after reviewing the literature in place identity theories, a framework was constructed to understand identity in terms of the three components - physical setting, activity, and meaning - based on the theoretical perspective of Relph (1976) and Montgomery (1998). To 
1 In this study, the name "Kızlarağası Inn" includes all the selected areas including the inn itself and its immediate surroundings. clarify how aspects of interiority establish identity, this study conducted a case study of Kızlarağası Inn and its close surroundings, defined as a "public interior". Kızlarağası Inn'1, located in the Kemeraltı neighborhood of İzmir in western Turkey, is a historical center and bazaar district. The inn's history shows how it is possible to grasp the elements that make it specific and valuable as a public interior. Until today, Kızlarağası Inn has been a place for social interaction, which indicates the social significance of this place.

A literature review of books, academic databases, reports, and articles was conducted to provide background information about interiority and place identity, besides the definitions and characteristics of public interiors and their components. To investigate the relationships between the indicators of public interiors and identity, data from Kızlarağası Inn concerning the three components of place identity were collected through archival research, field studies (observations, photoshoots, and behavioral maps), questionnaires, and interviews.

\section{LITERATURE REVIEW}

The notion of interiority is transformative, shaped by concepts of space and place through understanding the importance of social, cultural, physical, and technological developments within contemporary society. Taylor \& Preston (2006) define interiority as: "The conscious and reflexive awareness of self, identity, community and others within a social environment. Situated among philosophy and psychology, this cluster of associated points in the interdisciplinary arena of 'interiority' examines the innerness of interior design as that which is felt and projected upon and within the interior environment via the body as a culturally lived organism" (Taylor \& Preston, 2006, p. 11).

Interiority does not always define an indoor location. Similarly, the inside can also sustain exteriority. By breaking down this boundary, interior and exterior are not defined space but work simultaneously as one to provide everyday spatial experiences by creating opportunities for spatial engagement. McCarthy (2005) defines inside and outside as architectural prescriptions linked to the boundary of the building. However, interiority can be independent of the restriction of architectural buildings. Interiority and exteriority traverse the boundary of within and without. According to McCarthy (2005), for Wigley (1993), following Derrida (1988, 1991), interiority is built by identification and placement as mechanisms of domestication. For McCarthy, "enclosure is the encompassing aspect of closed space, implying the assertion of a boundary, and contributing with a deepness to the traditional notion of place in architecture" (McCarthy, 2005, p. 15).

By crossing their established spatial domain and facing the contemporary places of associated life, interior architecture and design have tried to expand and adapt their thematic horizon. The notion of interiority has overcome the boundary of the domestic environment to expand to public spaces of urban mobility, communication, and mass consumption 
(Peressut, 2010, as cited in Leveratto, 2019). In his book, The Architecture of the Well-Tempered Environment, Banham (1969) shifted the notion of interiority from the concept of bourgeois domestic solitude to that of a built environment characterized by its internal atmosphere, irrespective of any scalar or typological distinction (Banham, 1969, as cited in Leveratto, 2019).

According to this approach, urban spaces have interiority characteristics depending on their enclosure spread and consolidated throughout the decades. Within the context of everyday life in an urban neighborhood, inside and the outside can cross each other's boundaries, making it possible to be outside and experience interiority. Specifically, the boundaries of inside-outside are continually loosened because of everyday requirements. Various degrees of inside-ness and outside-ness appear in everyday urban spatial settings, with varying degrees of permeability of the boundaries between spatiality, and various forms of traversing the boundaries (Atmodiwirjo et al., 2015).

As contemporary public spaces, public interiors play a significant role in everyday twenty-first-century urban life (Poot et al., 2015). According to (Giunta, 2009), public interiors are places for studying the interaction between the human body and space, and the interaction between the community, objects, and space. (Harteveld, 2014) claims that in presentday Western society, many exemplary interiors are becoming part of urban life and urban structure. That is, interior public spaces cannot be avoided as a part of everyday life, and the increasing consideration of public space focuses on public interiors.

Interiority obtains its potency by reducing distance. It is a conception of closeness and the making of interactions. As McCarthy (2005, p. 117)puts it, "Interiority is a space (in time or place) of closeness and intimacy". In the ideological view, the strength of the border refers to the capability of the thin geometry of the boundary to convert interiority. Boundary conditions define the extent of interiority, as well as flexibility and mobility.

The formation of identity and typical place character is related to experiential processes. To make this understandable, people attach meaning to a place in trying to create a sense of place. A place entails different modes of spatial experiences, such as instinctive, bodily, and immediate, as well as more cerebral, ideal, and intangible ones (Seamon \& Sowers, 2008).

From the literature review, a framework was constructed, which consists of the attributes and elements associated with interiority, to investigate place identity through them (Fig. 1). 
Figure 1. Attributes and elements of place identity associated with interiority. (Created by the authors, 2019)

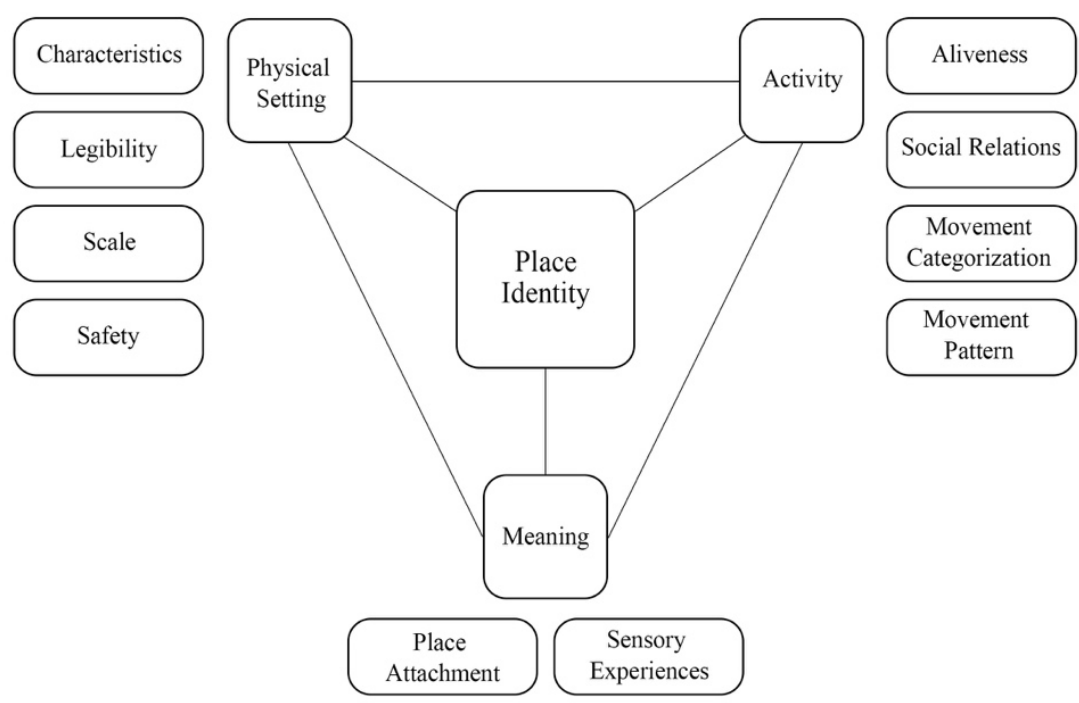

There are various senses between people and their experiences in a place. The characteristics of physical setting is one of the features that influence the identity of place. Therefore, by creating meanings, conceptions, and safeguarding their functions, the physical structures of place contribute to the identity of a place (Najafi \& Shariff, 2011).

The fundamental elements for studying the physical setting of a place in terms of interiority are legibility, scale, and safety. The legibility of a place and people's satisfaction with its environmental characteristics are factors that influence how people read the environment. In other words, a place's relationship with its surroundings determines its visibility, accessibility, and permeability, which in turn affect access and invitation (Whyte, 1980).

Interior space has many definitions. One aspect that defines the interior is the sensation of enclosure, based on the interior's distinguishing borders (either tangible and/or intangible) from exterior space, such as the interiors of buildings. They are spaces that we can perceive directly with our bodies. Interior space can be defined by human scale, meaning that everything in an interior space can be perceived by direct exposure. While people occupy a space, it is defined according to their perceptions of the environment, thereby through the body (Shirazi, 2014). When the human body is taken as the starting point for experiencing and explaining the environment, then the scale and atmosphere of spaces become definitive.

Relph defines the concept of identity with place "through the concept of insideness: the degree of attachment, involvement, and concern that a person or group has for a particular place" (Relph, 1976 as cited in Seamon \& Sowers, 2008, p. 45). Accordingly, "if a person feels inside a place, he or she is here rather than there, safe rather than threatened, enclosed rather than exposed, at ease rather than stressed. Relph suggests that the more profoundly inside a place a person feels, the 
stronger will be his or her identity with that place" (Seamon \& Sowers, 2008, p. 45).

To understand the effect of interiority in public space activities, it is necessary to consider aliveness as the attribute associated with being both internal and related to social relations, movement categorization, and movement patterns.

According to White (1999, p. 35), "a space can sometimes manifest behaviors, bring them into being". Activity is created by a place when human nature interacts with environmental opportunity. Places are associated with people's work, behavior, actions, leisure activities, and social activities, which relate to the environmental interaction that depends on the presence of others in public spaces. That is, activities connect humans to places (Najafi \& Shariff, 2011).

Aliveness is one of the attributes sensed about public space. It is supported by the intensity and diversity of activities created by pedestrian movement. All these activities represent the liveliness, energy, and enthusiasm of a place (Montgomery, 1998). Places that are densely populated with high energy and activity create more aliveness (White, 1999).

As two different categories of activity in public places, stationary behavior and movement refer to the level of pedestrian activity, primarily movement or staying and doing things. Movement means circulation, flow, origins, and destinations with the flowing people walking around and through the place and continuously creating motion. Foot traffic can be speedy and purposeful, as when people are on their way to work, or it may be slow and leisurely, as in a Sunday stroll for the joy of it. On the other hand, the place can be mainly activated by people involved in a wide range of stationary pursuits, such as sitting, watching, reading, eating, standing and talking, or taking photos (White, 1999).

The main approaches that specify meaning in relation to place identity are based on perceptions of place attachment and sensory experiences. Memories, expectations, alertness, culture, background, emotional state, life experience, values, and preferences can all influence the feeling of a location. Thus, (White, 1999) argues that the most immediate and tangible manifestation of the environment is the emotional content of a space. Public spaces are often bustling, busy places, full of energy and motion. This atmosphere is read with all our senses: sights, sounds, smells, tastes, and touch all melt within us to create the sense of the place. The form and degree of attachment are influenced by many factors including the socio-demographic characteristics and patterns of use. Collected experiences like 'fulfilling, terrifying, secure, or socially and culturally shared activities' are important factors in forming place attachments. Moreover, the geography of the place - its location, original features, and characteristics like landmarks, community structure, or unique public buildings - influence place attachment (Gieryn, 2000, as cited in Ujang \& Zakariya, 2015). 
The familiarity factor in place attachment can be understood by the degree of the place attachment of individuals. Places that are frequently used or visited have the highest levels of experience and are the most familiar. We should also bear in mind a strong relevance to local and historical contexts (Gustafson, 2001).

Generally, a place is comprehended in the way people experience it both physically and psychologically. People's memories, familiarization, the sense of place, and the meanings of spaces create place identity (Lai et al., 2013, as cited in Ujang \& Zakariya, 2015). The varied associations between people and places, which are influenced by personal and sociocultural contexts, create the place meaning (Ujang \& Zakariya, 2015).

As this review suggests, place identity can be studied through the attributes and elements outlined above. This study therefore provides just such a case study of a public interior, with its place identity analysis based on the above theoretical framework.

2 İzmir is Turkey's third largest city.

Figure 2. Location of Kızlarağası Inn. Adapted from Google maps, 2015.

\section{CASE STUDY: KIZLARAĞASI INN Historical Context}

Kızlarağası Inn, constructed during the $17^{\text {th }}$ century, is located in Kemeraltı district, for many centuries the historical center and bazaar district of İzmir² in western Turkey (Fig. 2). Since early times, İzmir has been a commercial port city, mainly because of ancient trade routes leading to its harbor. Since Kemeraltı remains one of the liveliest parts of İzmir, Kızlarağası Inn was lively as well as it was close to the harbor. The inn is a valuable example of Ottoman architecture in İzmir. By looking at the inn's history, it is possible to reveal the elements that make it unique and valuable as a public interior. Throughout its history, Kızlarağası Inn has been one of İzmir's meeting points and a place for social interaction, which indicates the social significance of this place.
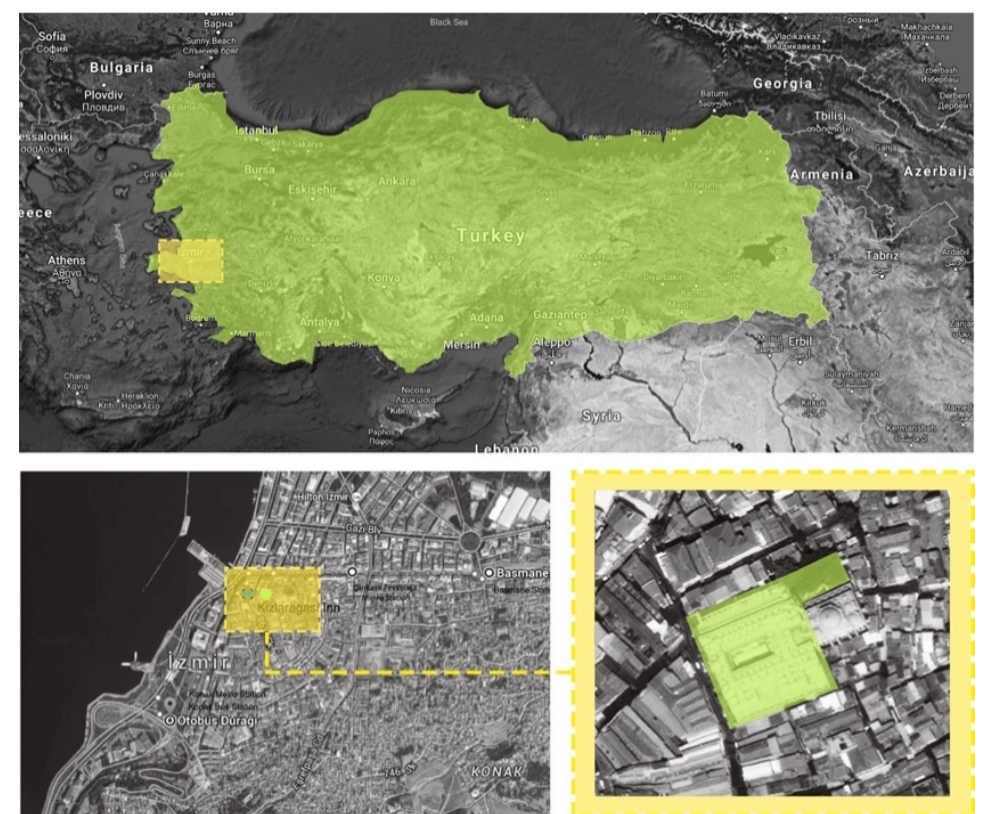


\section{Methodology}

This study has been conducted from a qualitative perspective. An informative background of place identity and its components, besides the definitions and characteristics of public interiors and interiority, were constructed through the literature research. The next stage determined the relationships between interiority attributes and the elements of public interiors and identity. To test this relationship, data about Kızlarağası Inn were obtained from archival research, field studies (observations, photoshoots, behavior mapping, and tracking), questionnaires, and interviews.

Observations were used to understand users' behavior in the place and their interaction with the physical surroundings. Asking basic questions such as what, where, why, and how activities play out there helped to systematize the observation.

Photography was used to document the visual character of the study site, activities, and situations. Photographs and video can elucidate the interaction between the chosen public and urban interiors and their users. Moreover, this method is a tool for fast freezing situations, revealing more detail by analyzing the documentation (photographs and video). In this study, the emphasis was thus not just on the physical setting but also on situations and interactions between place (public/urban interiors) and people (public users).

The sample population for the questionnaire and interviews included two groups with contrasting perspectives: tradesmen/women working in Kızlarağası Inn and academics living in Izmir with backgrounds in architecture and design. The first group provided information from the standpoint of frequent users who experience this place as part of their daily life while the second group provided the opinions of professionals who are occasional users of Kizlarağası Inn.

Specific questionnaires were designed for each group based on the kind of engagement they have with the inn. Participants were asked to indicate their agreement with various statements using Likert scales and multiple-choice grid questions. ${ }^{3}$

For the first group, responses were collected using printed questionnaires distributed by the authors. From a total of 60 printed questionnaires, a final sample of 44 questionnaires was gained, representing $22 \%$ of the inn's shop owners. The response rate was $95 \%$ in this group. For the second group, responses were collected online by sending the questionnaire as an email link. Of 220 academicians invited to participate, 118 responded, giving a response rate of $99 \%$.

Semi-structured, face-to-face interviews with seven questions were conducted with both groups. ${ }^{4}$ To get full and meaningful answers using the participants' knowledge and feelings, open-ended questions were asked. A total of six interviews were conducted with three participants from each sample group. The results are presented below, based on the relationship between the intended indicators of place identity and the users of the inn.

${ }^{3}$ A five-point scale was used with five pre-coded responses.

4 The original language of the interview questions was Turkish. 


\section{Analysis and Results}

This public interior's legibility makes it comprehensible for users. Having an accurate image of Kizlarağası Inn, they are able to orientate themselves and easily access its different parts (Fig. 3a, 3b.).

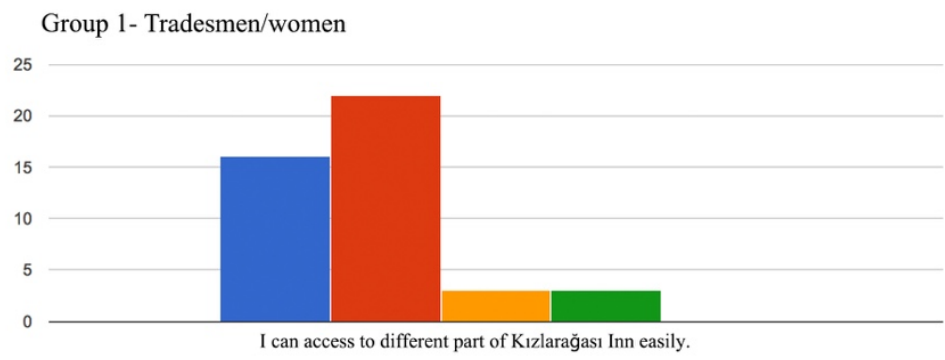

Group 2- Academicians

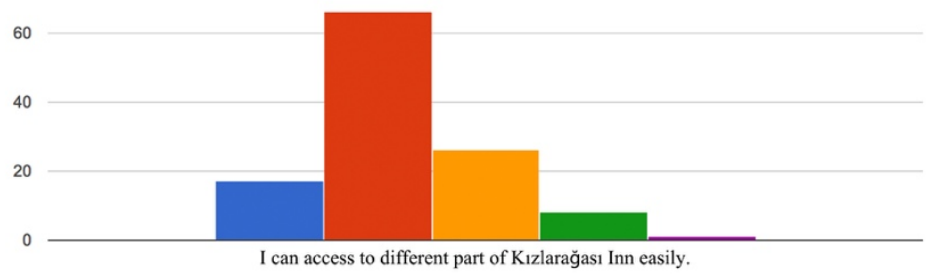

Figure 3a. Legibility of Kızlarağası Inn (Access)

Figure 3b. Legibility of Kızlarağası Inn (Orientation)

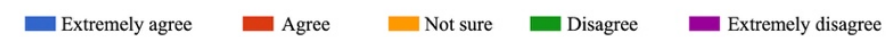

Group 1- Tradesmen/women

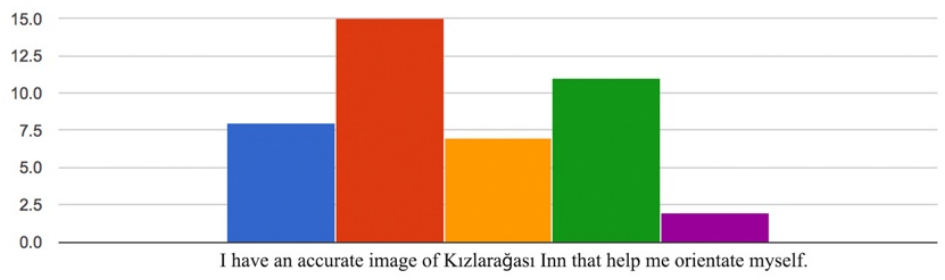

Group 2- Academicians

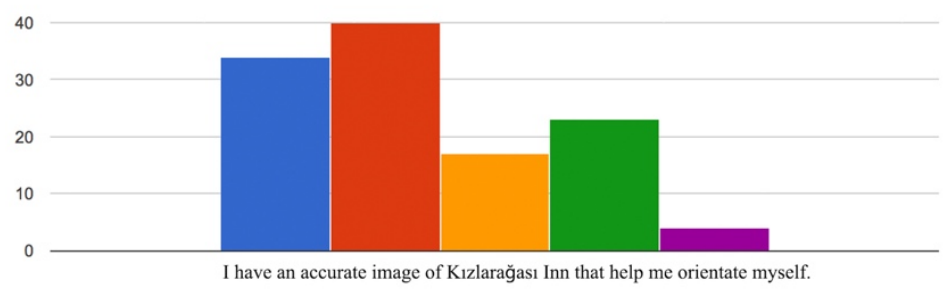

Extremely agree $\quad$ Agree $\quad$ Not sure $\quad$ Disagree $\quad$ Extremely disagree

The scale of the inn, which influences the understanding of inside as well as perceptions of the public interior was appropriate for its users (Fig. 4). By increasing perceptions of insideness, this feature enhances the legibility of Kızlarağası Inn. 


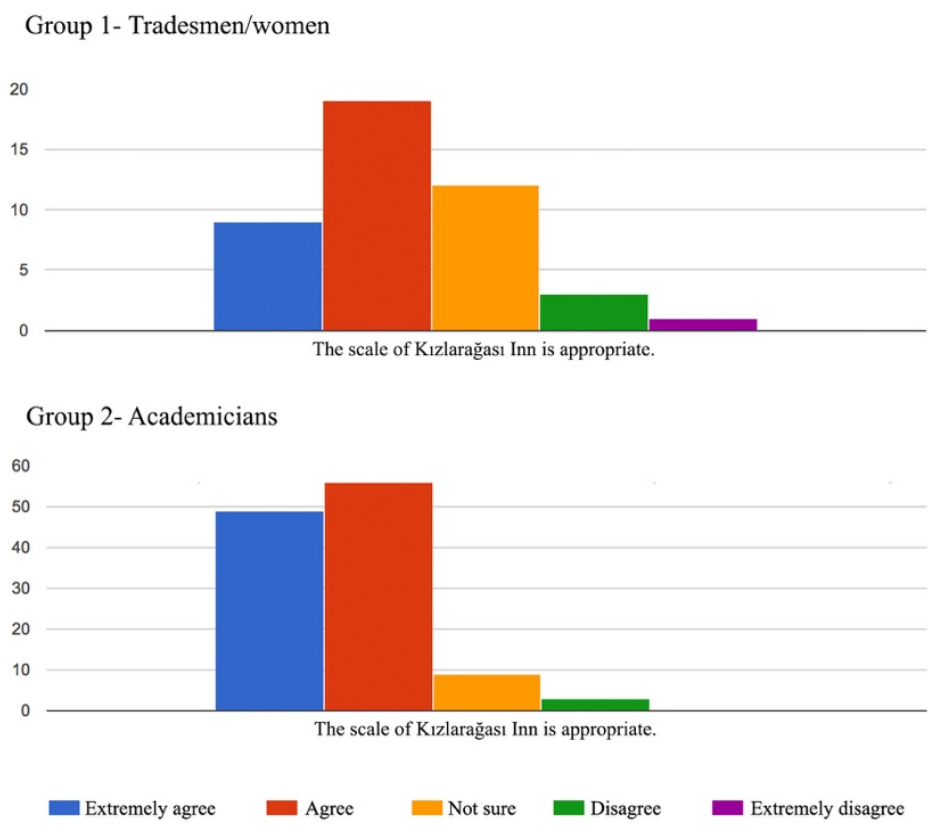

Figure 4. Scale in Kızlarağası Inn

Most users (80\% of tradesmen/women and $6 \%$ of academics) feel safe in Kızlarağası Inn, which can be explained by the above-mentioned interiority features of this place. The higher perceived safety of tradesmen/women than visitors can also be explained by their greater familiarity (Fig. 5).

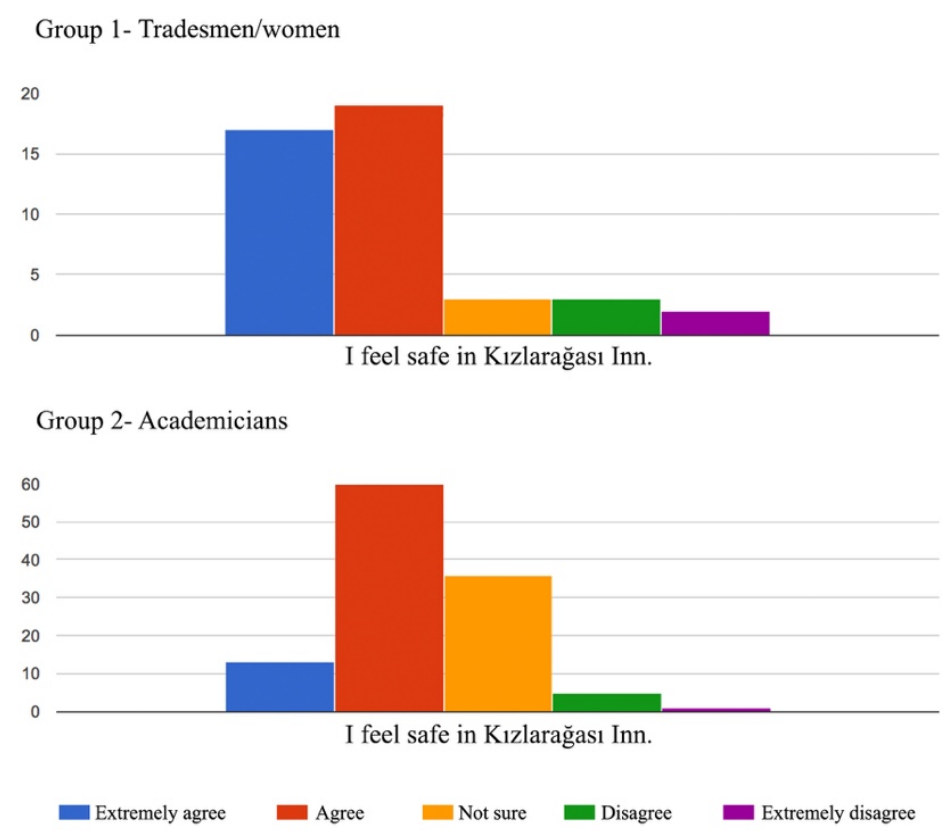

Figure 5. Safety in Kızlarağası Inn

Participants also sorted highlighted visual characteristics of Kızlarağası Inn. The findings suggest that the important attributes of the physical setting include volumetric properties, color and texture, plan layout, facade quality, and scale. These are the attributes that are most 
recognized by users, that influence their relationships with the place, and contribute to the sense of place. In short, as an interior, Kızlarağası Inn promotes several characteristics, particularly volumetric properties and scale (Fig. 6).

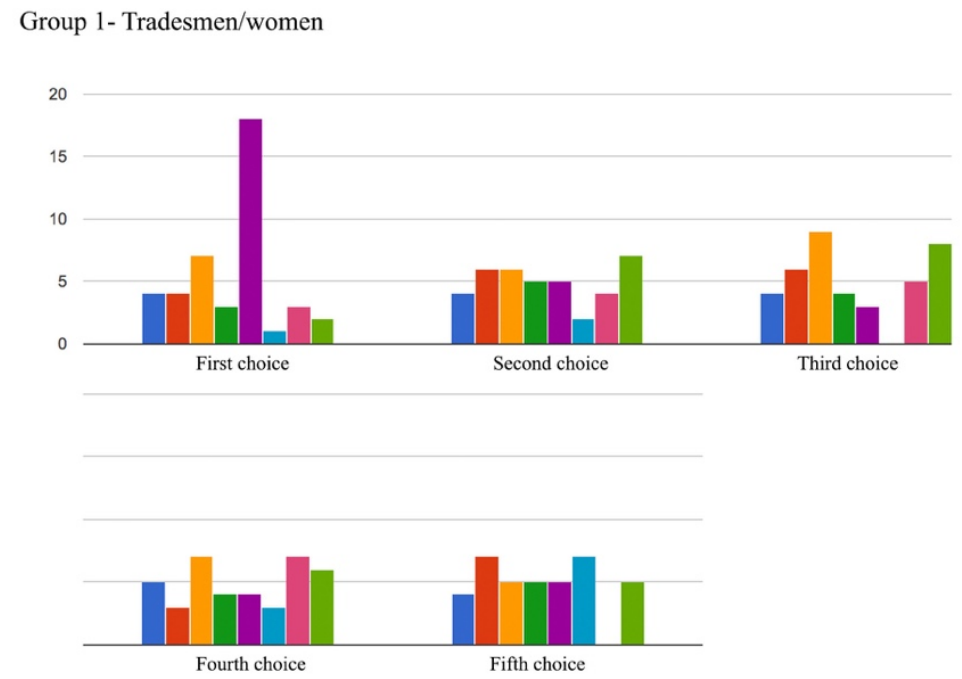

Group 2- Academicians

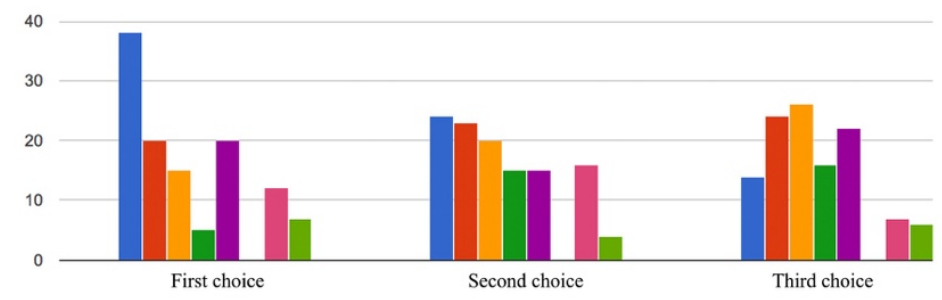

Figure 6. Selected visual characteristics of Kızlarağası Inn

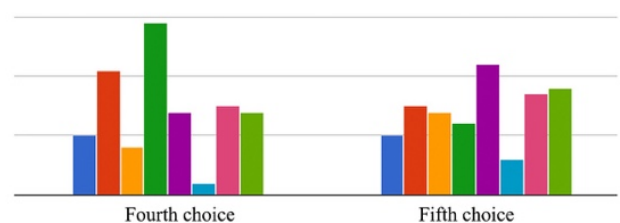

$\square$ a) Volumetric properties $\square$ b) Plan layout $\square$ c) Facade quality $\square$ d) Material

e) Color \& texture f) Street furniture g) Light (natural, artificial)

The inn attracts a large proportion of İzmir residents by its varied activities, commercial options, and vibrant environment (Fig. 7a, 7b). As one of the interviewees noted, Kızlarağası Inn is functioning well, it is creating a dynamic atmosphere which promotes activity and aliveness for its users. Nowadays, Kızlarağası Inn functions as a commercial center in line with its original purpose and the building's primary layout. In this regard, it is coherent, meaningful, and well-maintained. Current activities are relevant to real or factual life and current commercial conditions. Everything here is connected to daily life. This place provides a suitable environment where tradesmen/women can work happily and visitors 
are satisfied with the service they receive (Ş.E. Merter, interview, July 18, 2017).

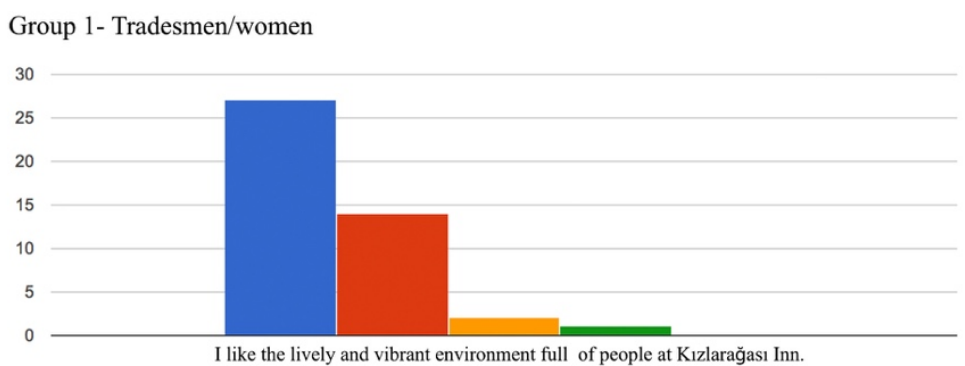

Group 2- Academicians

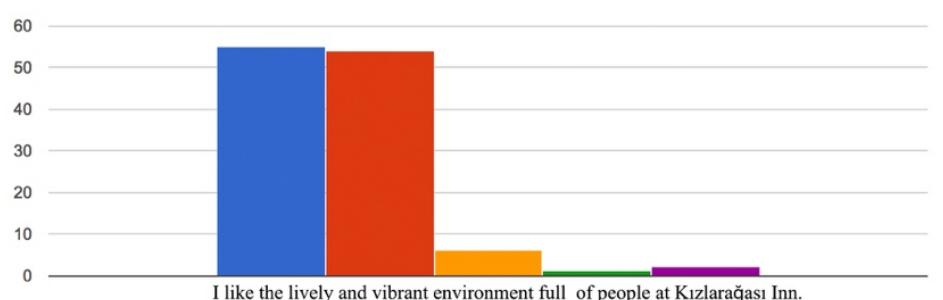

Extremely agree $\square$ Agree $\square$ Not sure $\square$ Disagree $\quad$ Extremely disagree

Group 1- Tradesmen/women

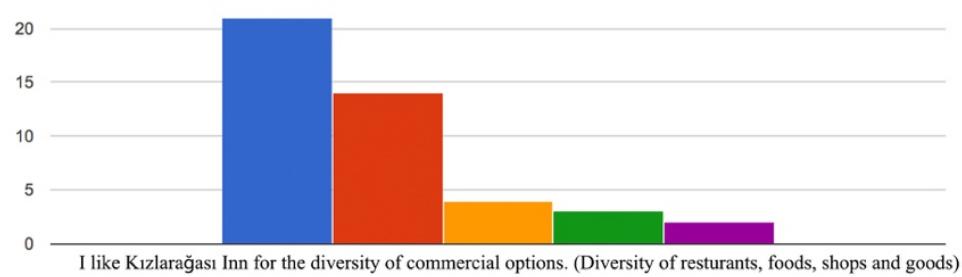

Group 2- Academicians

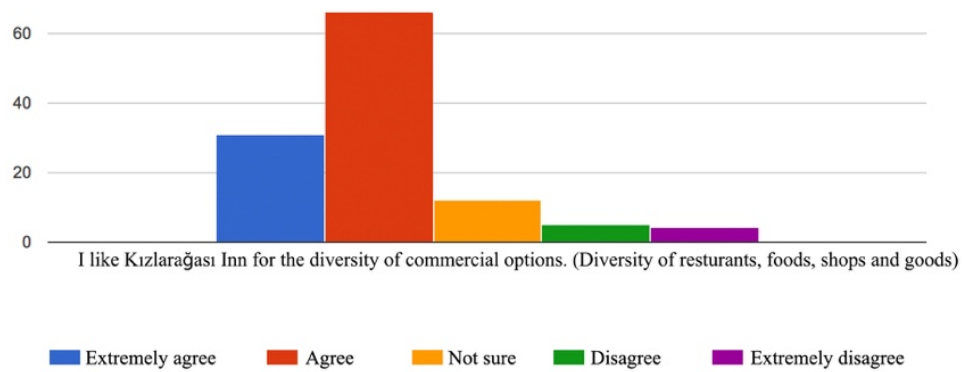

According to the participants, the activities inside Kizlarağası Inn both attract visitors and help develop social relations (Fig. 8). Besides the general potential of a public space to maximize people-people interaction, Kızlarağası Inn promotes a wide range of social activities. The socially shared activities increase social interaction, thereby developing social relations. In turn, they help create place attachment (Fig. 9).
Figure 7a. Diversity of activities at Kılarağası Inn (Internal atmosphere)

Figure 7b. Diversity of activities at Kızlarağası Inn (Commercial options) 
Figure 8. Activities developing social relations

Figure 9. Street music outside the main entrance of Kızlarağası Inn (Author's Archive, 2017)

Figure 10. Reasons to visit Kızlarağası Inn
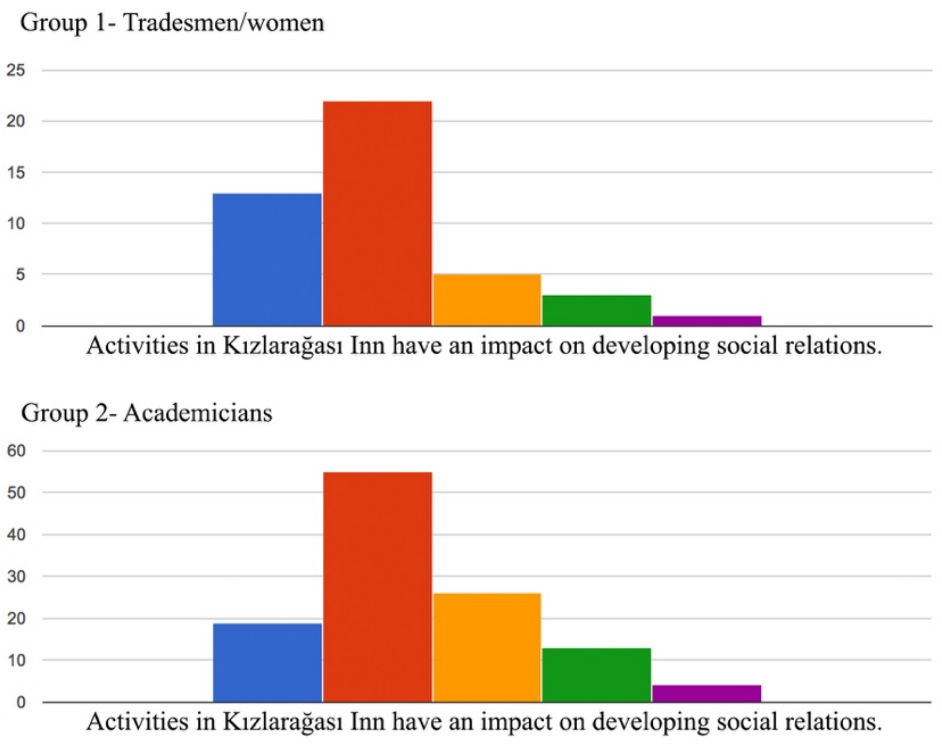

$$
\text { Extremely agree } \square \text { Agree } \quad \text { Not sure } \quad \text { Disagree } \quad \text { Extremely disagree }
$$

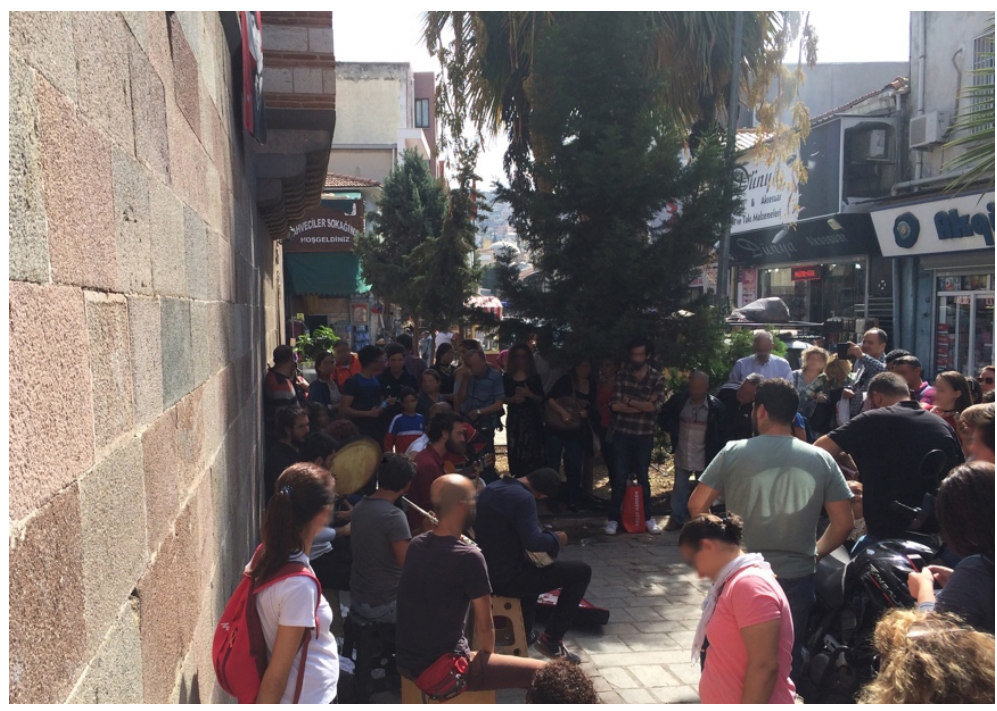

The academic participants were also asked why they visit Kızlarağası Inn. The most common purposes were strolling, drinking tea or coffee, or having a meal, followed by shopping, and meeting a friends or acquaintances (Fig. 10).

Group 2- Academicians

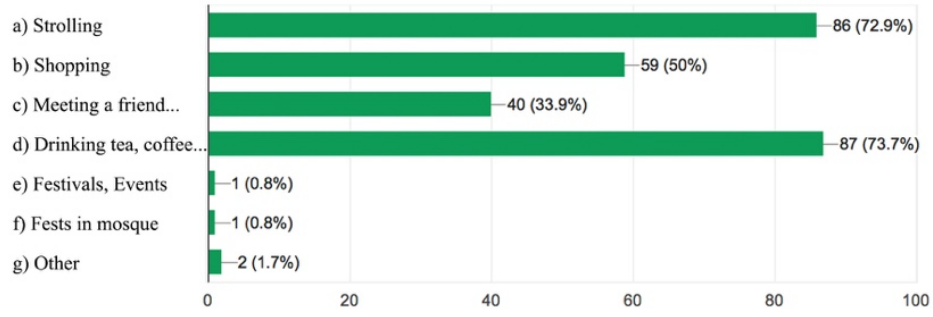


As one interviewee, İ. Alpaslan (head of Chamber of Architects in İzmir and Assistant Professor of History of Architecture at Dokuz Eylül University, Faculty of Architecture, interview, July 18, 2017) put it, having a drink and taking a rest at the yard of Kızlarağası Inn is a good escape from the din and the hot weather of Kemeraltı (Fig. 11). Merter (interview, July 18, 2017) noted how shopping has a historical background: Kızlarağası Inn had an important role in the history of Kemeralt. This inn had a significant function in terms of commerce. That is to say, it was an important center from past to present. ${ }^{5}$

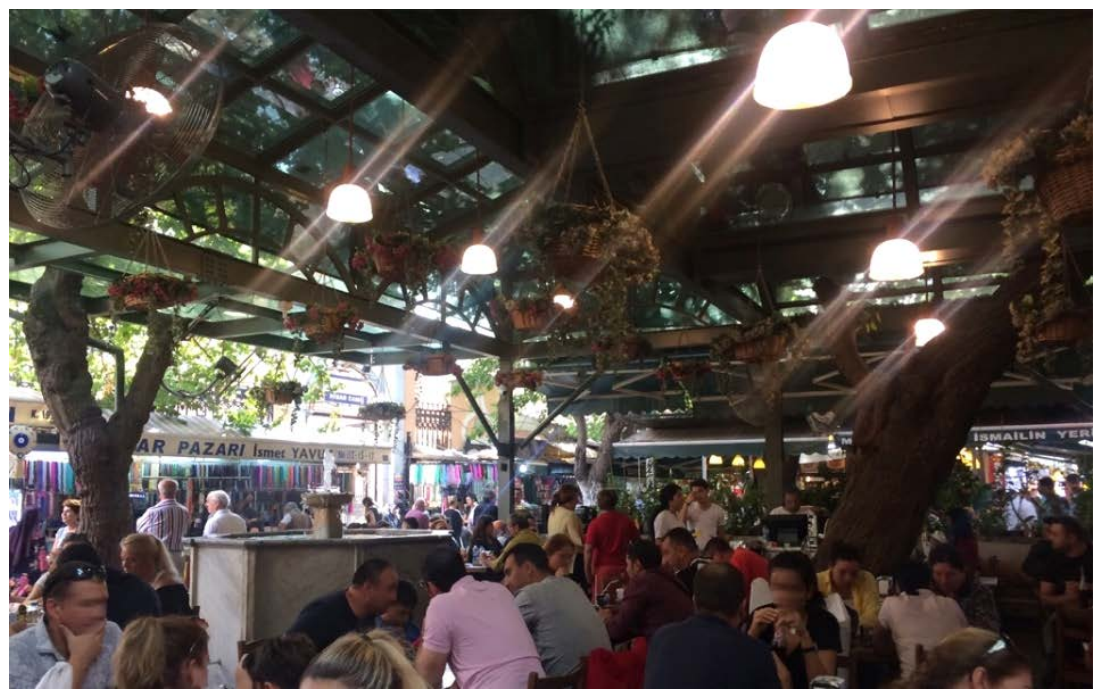

It should also be noted that almost half of the participants suggested more than one reason to visit the Inn (Fig. 12a) while over $70 \%$ drop by whenever they are in Kemeraltı Bazaar (Fig. 12b), as A. Yentürk (writer, researcher, and collector at Kızlarağası Inn, interview, 24 July, 2017), another interviewee, explained: "Well, here is a place where people cannot pass without stopping by if they are close." Moreover, Kızlarağası Inn also functions as a passage to Kemeraltı Bazaar (Fig. 12c) as its welldefined boundary, human scale, and feeling of safety invite people to pass through. V. Yıldız (musician at Kızlarağası Inn, interview, July 31, 2017) considered this in the interview by stating that anyone passing through the inn cannot ignore it; even people who try to shorten their way get involved because it is eye-catching. He adds that this place provides value for Izmir, which should be appreciated. This is why some visitors come from other neighborhoods to spend some time here and relax.

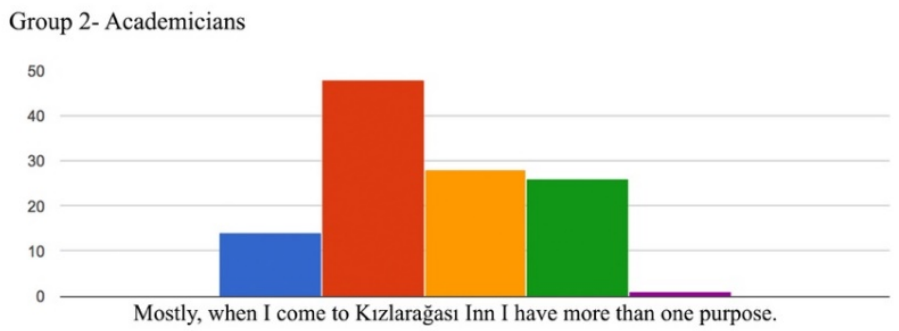

5 The original language of the interviews was Turkish, so all the quotations are translated into English for this paper.

Figure 11. Kızlarağası Inn, view of front yard (Hisarönü) (Author's Archive, 2017)

Figure 12a. Activity distribution in Kızlarağası Inn (Purpose of visit) 
Figure 12b. Activity distribution in Kızlarağası Inn (Routine)

Figure 12c. Activity distribution in Kızlarağası Inn (Passage)
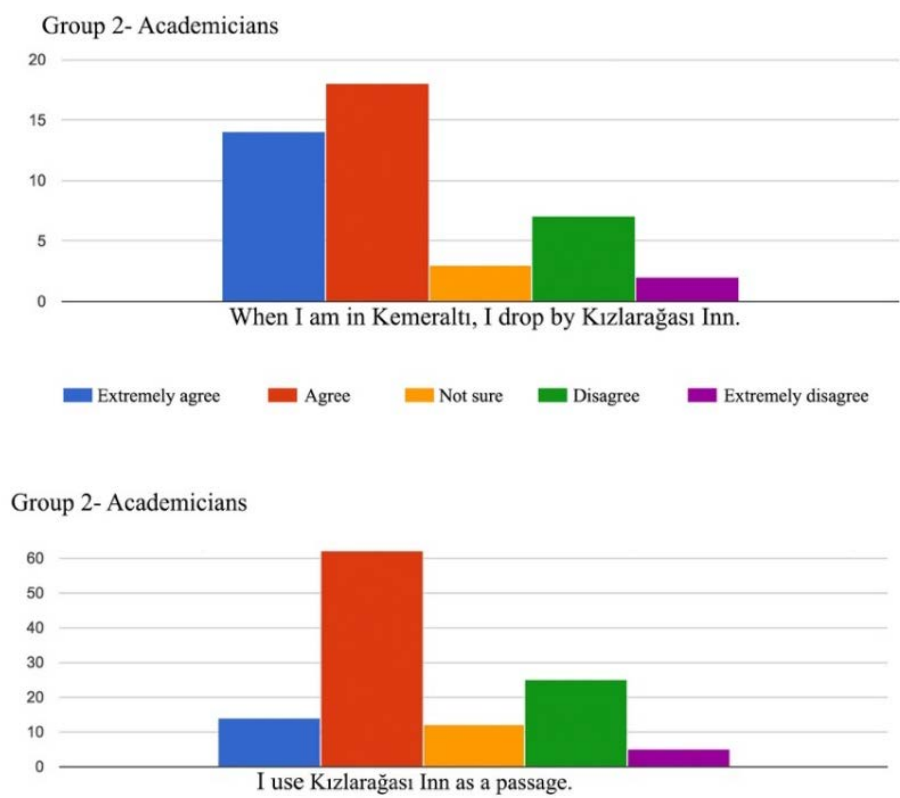

Behavior mapping of activities was conducted by plotting the positions of all people in Kızlarağası Inn involved in any sort of stationary or moving activities like walking, standing, and sitting. This determined where people and activities are concentrated, and where people position themselves relative to other people, buildings, and open spaces. People were recorded at Kızlarağası Inn over two days (weekend/weekday) for three different time periods (Table 1).

Table 1. Results of behavior mapping

\begin{tabular}{|c|c|c|c|c|c|c|}
\hline Place & \multicolumn{2}{|c|}{ Time periods } & Standing & Sitting & Walking & Total \\
\hline \multirow{6}{*}{ Courtyard } & \multirow{3}{*}{ Weekday } & Morning & 11 & 45 & 9 & 65 \\
\hline & & Noon & 11 & 84 & 17 & 112 \\
\hline & & Afternoon & 14 & 77 & 19 & 110 \\
\hline & \multirow{3}{*}{ Weekend } & Morning & 6 & 51 & 1 & 58 \\
\hline & & Noon & 1 & 80 & 9 & 90 \\
\hline & & Afternoon & 41 & 165 & 35 & 241 \\
\hline \multirow{6}{*}{$\begin{array}{c}\text { Ground } \\
\text { Floor } \\
\text { Passages }\end{array}$} & \multirow{3}{*}{ Weekday } & Morning & 10 & 4 & 3 & 17 \\
\hline & & Noon & 53 & 5 & 64 & 122 \\
\hline & & Afternoon & 75 & 12 & 84 & 171 \\
\hline & \multirow{3}{*}{ Weekend } & Morning & 21 & 2 & 14 & 37 \\
\hline & & Noon & 62 & 6 & 82 & 150 \\
\hline & & Afternoon & 67 & 12 & 81 & 160 \\
\hline \multirow{6}{*}{$\begin{array}{c}\text { First Floor } \\
\text { Passages }\end{array}$} & \multirow{3}{*}{ Weekday } & Morning & 9 & 5 & 11 & 25 \\
\hline & & Noon & 7 & 18 & 16 & 41 \\
\hline & & Afternoon & 8 & 25 & 4 & 37 \\
\hline & \multirow{3}{*}{ Weekend } & Morning & 7 & 2 & 8 & 17 \\
\hline & & Noon & 4 & 26 & 8 & 38 \\
\hline & & Afternoon & 8 & 56 & 31 & 95 \\
\hline
\end{tabular}


The findings show that the inner courtyard promotes stationary activities, with sitting to drink tea or coffee being the most common behavior. In contrast, the passages accommodated circulation as moving activities were most common there, as expected based on their function and users. In short, as a public interior, Kizlarağası Inn promotes a wide range of both stationary and moving activities that invite more people to participate.

The behavior mapping also showed that the inner courtyard is the most crowded area. Its semi-open areas are preferred over closed areas. In his interview, İ. Alpaslan (interview, July 18, 2017) pointed out how both weather and lifestyle influence this by stating that in Mediterranean cities, outdoor spaces are mostly preferred for living daily life. The local climate is the main reason for the popularity of inhabiting outdoor spaces. These semi-open areas are well-defined by a clear boundary, which increases the pleasure of being in an interior space.

Tracking was used to observe users' movement patterns in the inn, specifically by following a random selection of visitors over two days (weekend/weekday). The results indicated that visitors walk considerably faster on weekdays than weekends, presumably because the former tend to be more goal-oriented than the latter since people visit for pleasure at the weekends. The same conclusion applied to first-floor visitors since they tended to be goal-oriented with a specific destination in mind that affected their walking speed and time spent there. Finally, the observations showed that weekend visitors come in larger groups, of which a significant proportion are families, so most wander around before engaging in any stationary activities.

To sum up, the data provided a clear image of the activities promoted by Kızlarağası Inn and how people interact with this place. This information revealed the diversity of activities, the areas where they take place within this public interior, and the impact of its interiority on the diversity of users and their preferences.

Regarding preferences about Kızlarağası Inn, 60\% of participants selected its historical character as the most important feature, followed by its spatial quality and variety of activities (Fig. 13). Thus, the historical character and spatial quality of Kizlarağası Inn are two significant features. As a specialist in the history of architecture, İ. Alpaslan (interview, July 18, 2017) explained this factor in detail by stating that Kızlarağası Inn is one of the important remaining historical buildings from Izmir's commercial history. Apart from its historical significance and characteristics, Kızlarağası Inn is one of the most attractive places in Kemeraltı. He added that it is a building that improves the culture and life of the city because it is easily articulated with daily life.

He also noted that "its spatial quality is very high" (İ. Alpaslan, interview, July 18, 2017). D. Güner (professor at Dokuz Eylül University, Faculty of Architecture, interview, July 24, 2017), another interviewee (2017), agreed: "The inns in Kemeralt are inherited from the Great Fire of İzmir. Kızlarağası Inn is also important in that it is the first inn to have been 
opened for tourism in the historical area after having been restored. It is one of the basic reference points in Kemeraltl, and people from İzmir often visit there."

Because of these historical characteristics and its background, more people know about the inn, which increases its publicity. In addition, its wide range of activities and spatial quality make it both a landmark and a public place that people use.

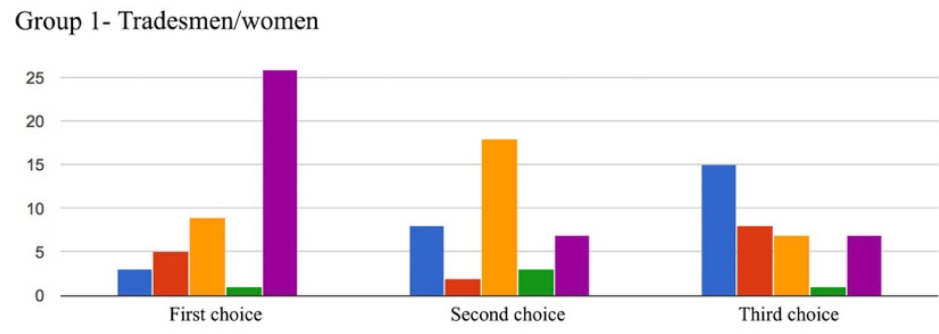

Figure 13. Participants' preferences about Kızlarağası Inn)
Group 2-Academicians

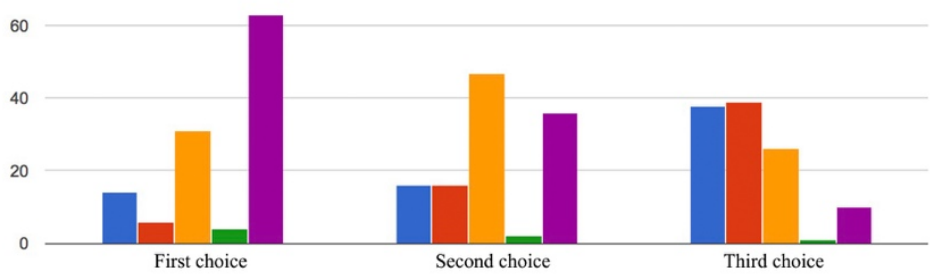

a) Variety of activities b) Familiarity c) Spatial quality of place d) My family has connections to this area from far back

The importance of the atmosphere of a public interior as a significant factor in its identity was true of Kızlarağası Inn for more than $90 \%$ of participants. As previously stated, atmosphere is read through all our senses that combine within us to provide a sense of the place. There are several findings regarding these sensory experience indicators. First, Kızlarağası Inn engages all senses: visual, auditory, olfactory, tactile, and gustatory (Fig. 14), although visual and olfactory sensations were most important (Fig. 15). As İ. Alpaslan (interview, July 18, 2017) noted, "Kızlarağası Inn appeals to all five senses. However, as an auditory experience, it is a different part of Kemeraltı. That is to say, when you come inside the inn, the acoustic structure changes. It smells different, too. In this regard, the lack of vehicles can be mentioned as a reason". This statement confirms that the interiority of Kizlarağası Inn is a significant factor in the sensory experiences of users. That is, this place, as an interior, promotes a different sensory context to the outside environment. 

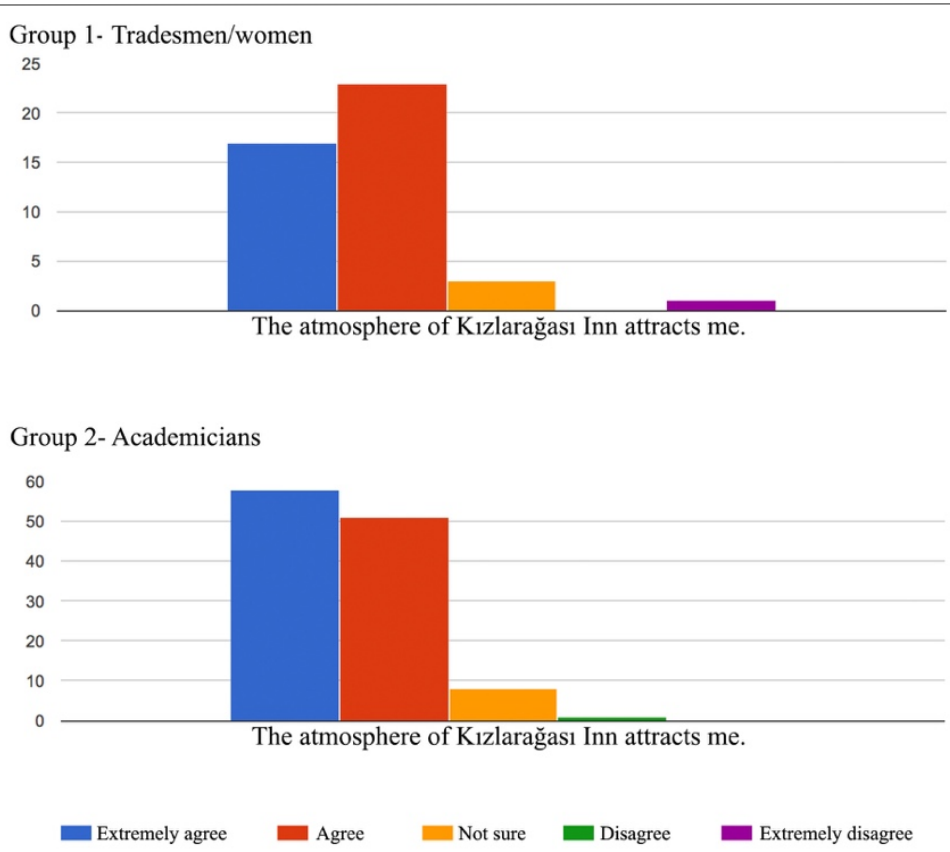

Figure 14. Sensory experiences of Kızlarağası Inn's users

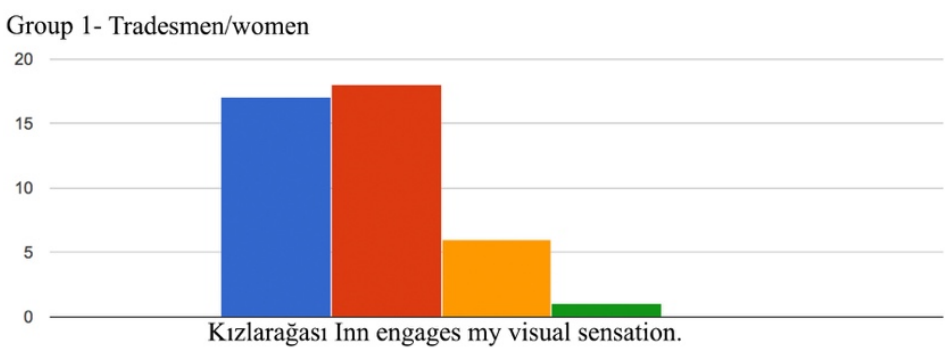

Group 2- Academicians

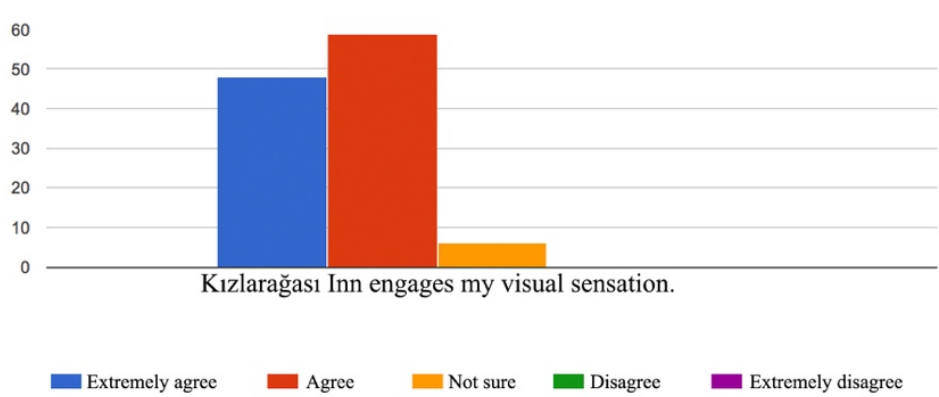

Figure 15. Visual sensory experiences of Kılarağası Inn's users

The inn's interior creates a specific auditory environment that creates the atmosphere of the place and the sensory experiences of the inn's users. For example, users reported that it is pleasant to escape the traffic noise in this interior (Fig. 16). Another influential feature is music, which was mentioned by several interviewees: "The existence of the flute course here has a great influence on us" (G. Güler, antiquarian at Kızlarağası Inn, interview, July 21, 2017). V. Yıldı (interview, July 31, 2017), who is specialized in this music (Turkish flute, ney), noted how the flute performance in the historical atmosphere involves people emotionally. Another interviewee stated that every item in Kızlarağası Inn was attractive, but from his perspective the most important thing was feeling 
peaceful and delighted there, and clarified this as his reason for being there at every opportunity (S..E. Merter, interview, July 18, 2017). While V. Yıldız (interview, July 31, 2017) noted that the inn attracts visitors with its historical character and its old texture and makes them physically and emotionally involved.

Figure 16. Auditory sensory experiences of Kızlarağası Inn's users

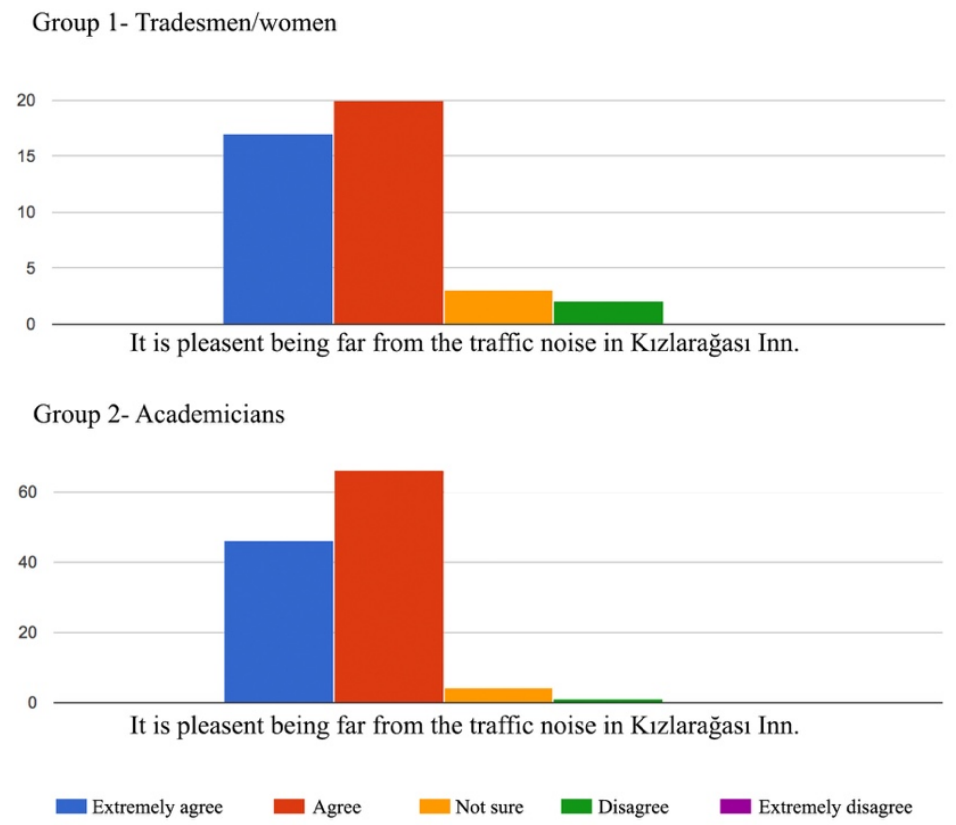

The responses to the attachment-based statements indicated that participants are attached to the inn. The highest agreement scores were for the following two statements: "If Kizlarağası Inn is under threat (of being demolished), I will defend it" (Fig. 17a) and "When I have guests from other cities or countries, I take them to Kizlarağası Inn” (Fig. 17b). T. Taner (professor of Urban Design at Yasar University, Faculty of Architecture, interview, July 17, 2017) recalled that he took foreign guests there several times and all of them liked the place. He believes that foreigners like it because it is the most characteristic place in Kemeraltı. This sense of attachment toward Kızlarağası Inn was further confirmed by the interviewees through their feelings, emotions, and behavior, as in the following statements. For D. Güner (interview, July 24, 2017), Kızlarağası Inn is a place where public have in mind and associate it with memories, while İ. Alparslan (interview, July 18, 2017) explained that, as a historian with an interest in the history of the city, he feels bonded with this place. Moreover, he saw Kizlarağası Inn as an important historical structure of İzmir that has brought many characteristics of İzmir's history to the present. T. Taner (interview, July 17, 2017) declared that he admires the inn and enjoys going there. He considers this place as a successful public space, where is pleasant to rest and drink coffee. He also confirmed that there is no other lively place working as well as Kızlarağası Inn for tourism (T. Taner, interview, July 17, 2017). 

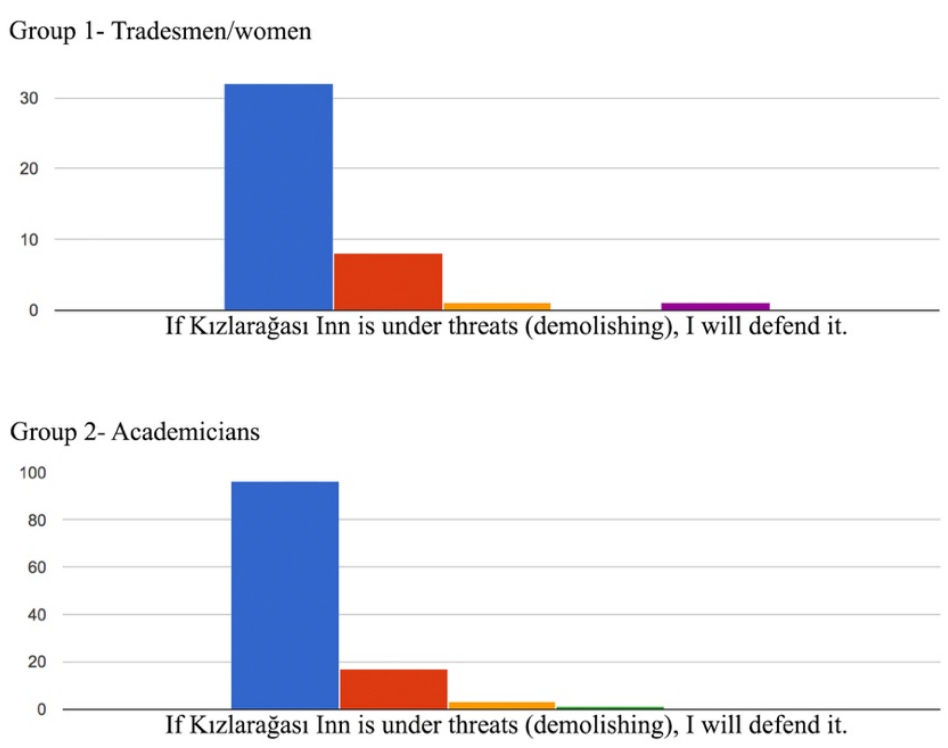

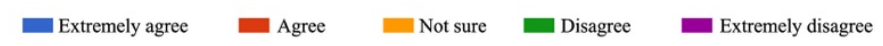

Group 1- Tradesmen/women
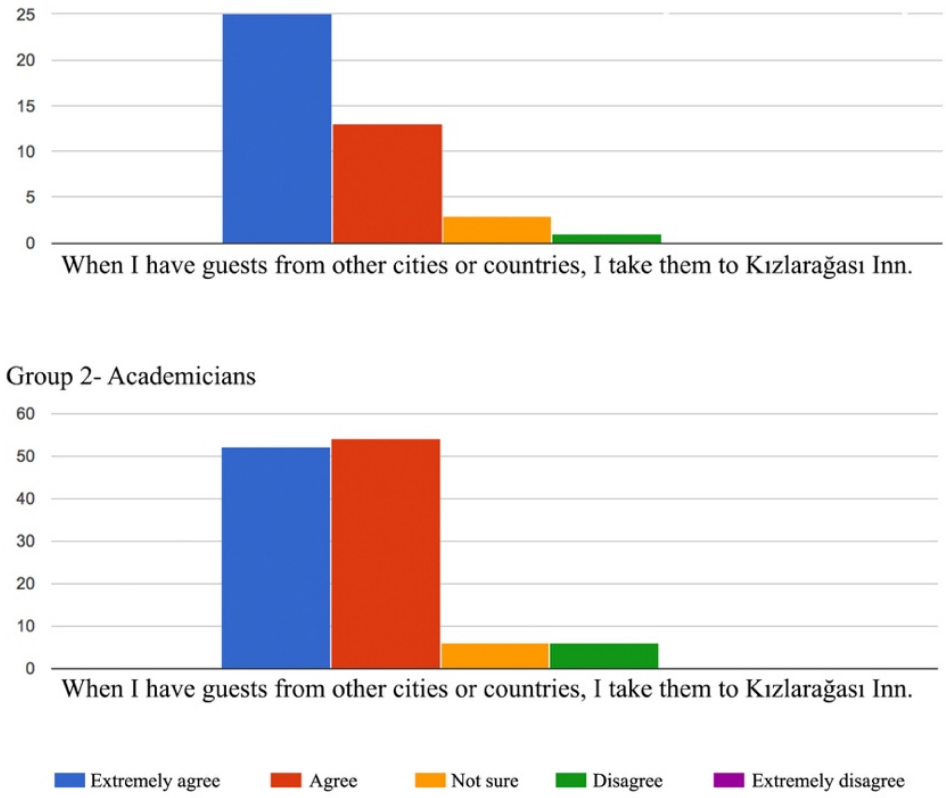

The study shows that a large percentage of visitors have many fond memories of Kızlarağası Inn, which could explain their sense of attachment to this place and make the existence of this interior valuable. Thus, place identity is developed through people's memories (Fig. 18). Several experiences were narrated by interviewees regarding their memorable moments in Kızlarağası Inn:

What I remember as the most delightful memories from my internship in Kemeraltı during the hot days is our routine of meeting in Kızlarağası Inn and drinking coffee there. Both physically and mentally, it was an unforgettable experience for me to go into the cool interior of the inn. I
Figure 17a. Attachment of users to Kızlarağası Inn (Endurance)

Figure 17b. Attachment of users to Kızlarağası Inn (Historical Heritage) 
remember that I used to like going through the inn although it made my way longer (İ. Alpaslan, interview, July 18, 2017).
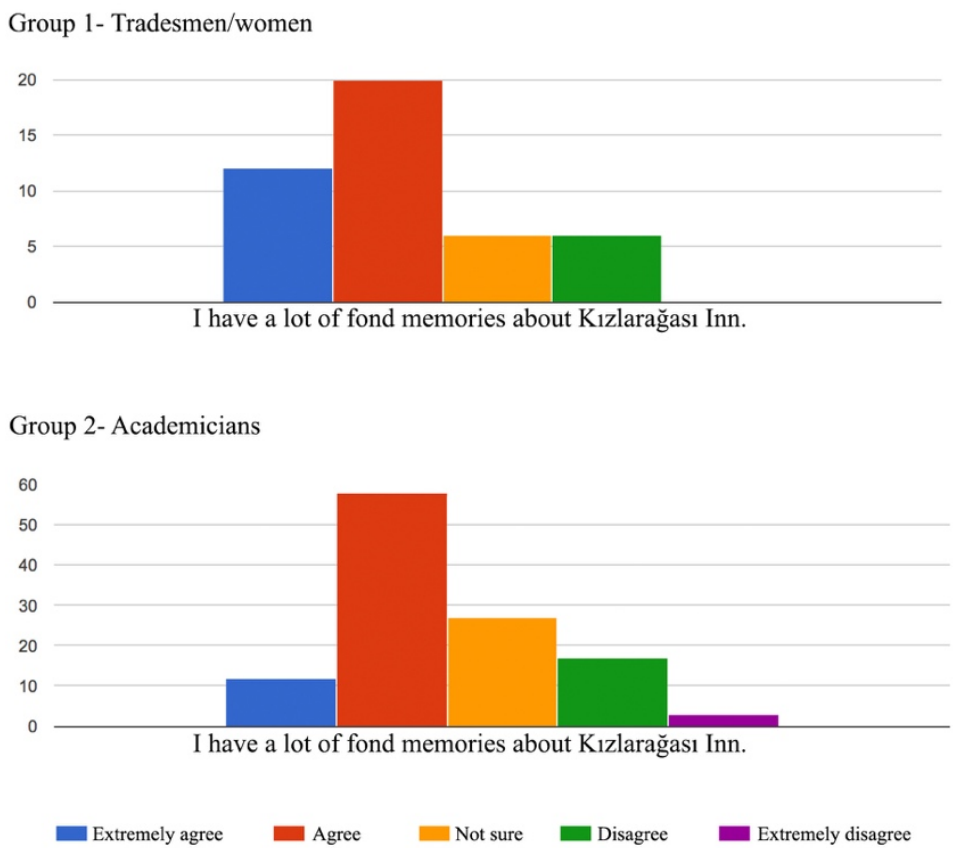

Figure 18. Place memory of Kızlarağası Inn's users
Extremely agree $\quad$ Agree $\quad$ Not sure $\quad$ Disagree $\quad$ Extremely disagree

As İ. Alpaslan (interview, July 18, 2017) noted, as an interior, Kızlarağası Inn promotes the pleasure of being in it, which invites its users to participate in activities or just pass through its passages. B. Üzmez (photographer, interview, 13 July, 2017) explained his photographic memories in Kızlarağası Inn:

As a photographer, I should admit that taking photographs there has always been interesting to me. Not only the inn itself, which can be captured from outside and inside, but also people and activities can be photography subjects. When I was at IFOD (İzmir Photography Art Association), around four years ago, we carried out a documentary photography project about Kemeraltı with nine friends. During that period, we visited the inn often to take photographs. We took photographs of record sellers, antique shops, gramophones, and flute players and their workshops. It was an interesting memory for me.

E.Ş. Merter (interview, July 18, 2017) also emphasized that every moment while taking photographs there provided outstanding memories.

Besides the previously discussed interiority features of the inn, like its physical and historical characteristics, and its specific sensory context, these memories demonstrate that Kızlarağası Inn has great potential to address various groups of users and offer opportunities for each group to experience this place in their own way. Thus, all the participants reported fond memories related to this place and their experiences of its atmosphere. These are then transformed into strong emotional links stimulating their attachment that determine its social value. 


\section{CONCLUSIONS}

Based on the analysis in this study, the most important interiority aspects in the place identity framework of Kızlarağası Inn can be summarized as follows.

Previous studies have shown that legibility, volumetric properties, welldefined boundaries, and nearness to human scale are key attributes and elements of the physical setting that influence how users relate to a place and contribute to its place identity. In the case of Kızlarağası Inn, the interiority of the public space is a significant factor for developing this relationship.

In addition, the data reveal that the inn's positive effects on users stem from its appropriateness for Izmir's climatic conditions, culture, and lifestyle in terms of the available areas and functions of this interior.

While any public space should promote the greatest amount of peoplepeople and people-place interaction, public interiors specifically promote a wide range of activities addressing different groups of users. In the case of Kızlarağası Inn, its historical character, spatial quality of place, variety of activities, and different sensory contexts increase its popularity; that is, people know it, like it, and use it. The ability to encourage a variety of activities and different sensory contexts stems from the interiority of place, which provides sensory experiences and fond memories for users. This study's findings thus demonstrate the positive role of interiority in place identity components. Regarding attributes and elements of meaning in Kızlarağası Inn, the effects of place identity in public interiors are related to both the physical and social environment. That is, a place's physical setting, activities, situations, and events, the individual and group meanings created through people's sensory experiences, attachments, involvement, memories, and intentions towards these places all play a role in creating place identity.

This study emphasized the importance of public and urban interiors in interior architecture. Moreover, it showed the extension of interior spaces outside the buildings, which reflect on interior designers by bringing a new understanding of the interior and its extension in terms of the design task with its contingencies to other design fields and disciplines.

Furthermore, this study emphasized a new perspective for urban designers who, when dealing with public space, traditionally focus on outdoor public spaces as a public domain or publicly owned spaces. This perspective notes the existence of public spaces inside buildings that include both publicly and privately owned spaces.

This study highlighted the importance of these public places as part of everyday life in an urban environment. Further studies could provide more insights by observing interiors like Kizlarağası Inn from different perspectives while considering the features that define them as interiors. For instance, longitudinal analyses of public interiors could provide insights into changes in contemporary cities and help us learn from the history of the design of public interiors for future urban environments. 
Finally, it is important to acknowledge that public and urban interiors are significant places that facilitate public life, where people come together for social reasons, besides religious, civic, and marketing functions. In this respect, they can be considered as an influential part of the public realm that can significantly contribute to urban life to make cities more livable.

\section{ACKNOWLEDGEMENTS}

We would like to thank the academicians and Kılarağası Inn's tradesmen/women who kindly accepted to participate in the questionnaire. Without them, this study would not have been possible.

We would like to extend our thanks and appreciation to Prof.Dr. Deniz Güner, Prof.Dr. Tayfun Taner, Assist.Prof.Dr. Halil İbrahim Alpaslan, Gülten Güler, Arya Kamali, Şerif Erdal Merter, Ahmet Cengiz Şerefli, Birol Üzmez, Volkan Yıldız, and Aybala Yentürk for their time and co-operation. Their enthusiastic sharing gave us useful materials to do the analysis.

\section{CONFLICT OF INTEREST}

There is no conflict of interest was declared by the authors.

\section{FINANCIAL DISCLOSURE}

The authors declared that this study has received no financial support.

\section{ETHICS COMMITTEE APPROVAL}

Ethics committee approval was not required for this article.

\section{LEGAL PUBLIC/PRIVATE PERMISSIONS}

In this research, the necessary permissions were obtained from the relevant participants (individuals, institutions, and organizations) during the survey and in-depth interviews.

\section{REFERENCES}

Atmodiwirjo, P., AndriYatmo, Y., \& Ujung, V. A. (2015). Outside interior: traversed boundaries in a Jakarta urban neighbourhood, Idea Journal, 15(1), 78-101.

Carr, S., Stephen, C., Francis, M., Rivlin, L. G., \& Stone, A. M. (1992). Public Space. Cambridge University Press.

Giunta, E. E. (2009). Urban interiors. artificial territories. designing 'spatial script' for relational field, Idea Journal, 9(1), 52-61.

Gustafson, P. (2001). Meanings of place: everyday experience and theoretical conceptualizations, Journal of Environmental Psychology, 21(1), 5-16.

Harteveld, M. (2014). Interior Public Space; on the Mazes in the Network of an Urbanist.

Leveratto, J. (2019). Urban interiors: a retroactive investigation, Journal of Interior Design, 44(3), 161-171.

McCarthy, C. (2005). Toward a definition of interiority, Space and Culture, 
$8(2), 112-125$.

Montgomery, J. (1998). Making a city: urbanity, vitality and urban design, Journal of Urban Design, 3(1), 93-116.

Najafi, M., \& Shariff, M. (2011). The concept of place and sense of place in architectural studies, International Journal of Human and Social Sciences, 6(3), 187-193.

Poot, T., Van Acker, M., \& De Vos, E. (2015). The public interior: the meeting place for the urban and the interior, Idea Journal, 15(1), 44-55.

Relph, E. (1976). Place and Placelessness (Vol. 67). Pion London.

Seamon, D., \& Sowers, J. (2008). Place and placelessness (1976): Edward Relph, Key Texts in Human Geography, 43-52.

Shirazi, M. R. (2014). Towards an Articulated Phenomenological Interpretation of Architecture: Phenomenal Phenomenology. Routledge.

Taylor, M., \& Preston, J. (2006). Intimus: Interior Design Theory Reader. John Wiley \& Sons Inc.

Tibbalds, F. (2012). Making People-friendly Towns: Improving the Public Environment in Towns and Cities. Taylor \& Francis.

Ujang, N., \& Zakariya, K. (2015). The notion of place, place meaning and identity in urban regeneration, Procedia-Social and Behavioral Sciences, 170, 709-717.

White, E. T. (1999). Path--Portal--Place: Appreciating Public Space in Urban Environments. Architectural Media.

Whyte, W. H. (1980). The social life of small urban spaces [Motion picture]. Santa Monica, CA: Direct Cinema Limited.

\section{Resume}

Sahar Asadollahi Asl Zarkhah received her bachelor's degree in architecture from PNU University, Department of Architecture in 2011 and her graduate degree in interior architecture from Yaşar University, Department of Interior Architecture in 2018. Her main research interests include public and urban interiors, environmental psychology, and socio-cultural studies in architecture.

Zeynep Tuna Ultav received bachelor and master's degrees in architecture from METU, Department of Architecture; and PhD degree from Gazi University, Department of Architecture. She is currently the department head at Yaşar University, Department of Interior Architecture and Environmental Design. Her research interests include History and Theory of Interior Architecture; Modern Architecture.

Gülnur Ballice obtained her undergraduate, master's, and Ph.D. degrees from the Department of Architecture at Dokuz Eylül University, METU, and Dokuz Eylül University, respectively. She is currently working as an academician at Yasar University. Her research topics include urban transformation/renewal, modern architecture/interiors, design studio education, healthcare interiors, and housing. 